Куртсеітов Т. Л., д-р техн. наук, професор, (ORCID 0000-0001-6478-6469); Павлунько М. Я., канд. військ. наук, $\quad$ (ORCID 0000-0001-8255-6245); Посмітюх О. I., канд. військ. наук, доцент (ORCID 0000-0002-4467-9532)

Інститут забезпечення військ (сил) та інформаційних технологій Національного університету оборони України імені Івана Черняховського, Київ

\title{
Основні виклики та загрози Російській Федерації у військовій сфері: основа застосування ії̈ збройних сил на південно-західному стратегічному напрямку
}

Резюме. У статті на основі аналізу положень нової Стратегії національної безпеки Російської Федерації, військової доктрини і наукових публікацій у яких розглядаються зовнішня політика Росії, сформульовані стратегічна мета зовнішній політики Росії, основні пріоритетні напрями у сфері національної безпеки, які визначені перед Збройними Силами Російської Федерації, перелік основних викликів та загроз Російській Федерації у військовій сфері.

На основі переліку основних викликів та загроз визначені основні завдання, які ставляться перед збройними силами Росії та основні форми їх застосування у воєнних конфліктах.

Спираючись на аналіз задумів навчань, які були проведені Російською Федерацію останніми роки, в статті надано висновки щодо сценаріїв війн та збройних конфліктів з Україною, Грузією, США/НАТО, Японією та Китаєм, а також проведення контртерористичних операцій на російській території, які плануються.

Зазначено, що ситуація довкола України становить основну загрозу їі національній безпеці, залишається ймовірна збройна агресія Росії, яка, незважаючи на певне зниження інтенсивності бойових дій на Донбасі, готова до військового вторгнення в Україну, зокрема, у вигляді проведення миротворчої операції або повномасштабної наступальної операції.

Ключові слова: виклики; загрози; військова сфера; стратегічний напрямок.

Постановка проблеми. Протягом останніх років перехід Російської Федерації (РФ) до проведення активної політики щодо встановлення російського контролю над пострадянським простором та конфронтації із Заходом призвів до відновлення протистояння між Росією і Заходом (НАТО, США) фактично на рівні “холодної” війни.

Отже в умовах сучасної Росії збройні сили країни є одним із основних інструментів з реалізації іiі зовнішньої, а за певних обставин, і внутрішньої політики.

Огляд останніх досліджень i публікацій. На сьогодні у Воєнній доктрині Росії [1], яка була прийнята в грудні 2014 року та доопрацьована, на основі положень нової Стратегії національної безпеки Російській Федерації [2] від 2015 року трактуються основні виклики та загрози Російській Федерації у військовій сфері. Це питання також досліджується в таких публікаціях:

[3] - проведено аналіз завдань бойового застосування ЗС РФ на основних стратегічних (операційних) напрямках;

[4] - розглянуто історичні етапи реалізації стратегії і тактики Росії;
[5] - розглянуто теперішнє перетворення Росії на "планетарну”, а в перспективі “вселенську” гіпердержаву;

[6] - здійснено аналіз воєнно-політичних наслідків розвитку ситуації довкола України.

Отже, на основі проведеного аналізу останніх публікацій можна дійти висновку, що питання основних викликів і загроз Російській Федерації у військовій сфері потребують подальшого дослідження. А також необхідно відмітити, що аналіз застосування ЗС РФ, особливо під час війни 3 Україною, на Південно-Західному стратегічному напрямку, на сьогодні є актуальним.

Мета статті. У процесі аналізу положень Стратегії національної безпеки РФ та Воєнної доктрини Росії, виділити основні виклики та загрози РФ у військовій сфері. На основі визначених викликів та загроз проаналізувати загальні завдання збройних сил Росії, зокрема, на Південно-Західному (Українському та Чорноморському) стратегічному напрямку.

Виклад основного матеріалу. Стратегічною метою зовнішньої політики Росії $\epsilon$ відновлення свого геополітичного статусу у світі, самоствердження після розвалу 90-х років, у ближньому зарубіжжі - 
реінтеграція пострадянського простору, створення союзу колишніх радянських республік (ймовірно, виключаючи лише країни Балтіі) за зразком ЄС.

Пріоритети у сфері національної безпеки поставили перед Збройними Силами Російської Федерації такі завдання, які можуть бути структуровані за двома основними напрямами:

стримування військових i військовополітичних загроз безпеки або посягань на інтереси Російської Федерації;

захист економічних i політичних інтересів Російської Федерації.

Ïх наповнення визначено в Стратегії національної безпеки РФ та Воєнній доктрині Росії. Зокрема, у Воєнній доктрині Росії та новій Стратегії національної безпеки РФ основними викликами та загрозами Російській Федерації у військовій сфері є [1-3]:

нарощування силового потенціалу НАТО, розширення Альянсу та наближення його військової інфраструктури до кордонів РФ, розгортання США системи стратегічної протиракетної оборони (ПРО), розміщення озброєнь у космосі та реалізація Вашингтоном концепції “глобального удару” - таким чином США та НАТО фактично визнані основними противниками РФ;

територіальні претензії до Російської Федерації та ¥іi союзників, а також зовнішні втручання у їх внутрішні справи - в основі визначених загроз, робиться безпосередній натяк на Китай та Японію, які є країнами, що мають територіальні претензії до Росії;

встановлення у державах, суміжних 3 Російською Федерацією, режимів, зокрема в результаті повалення легітимних органів державної влади, політика яких загрожує інтересам Росії - по суті, прямо вказується на Революцію Гідності в Україні та прихід до влади в країні національно-демократичних сил прозахідної спрямованості;

наявність (виникнення) вогнищ та ескалація збройних конфліктів на території держав, сусідніх із Росією та іiі союзниками фактично маються на увазі конфлікти на Сході України, в Абхазії, Північній Осетії та у Нагірному Карабаху, які саме i були спровоковані Російською Федерацією;

діяльність, спрямована на насильницьку зміну конституційного ладу в Росії, дестабілізацію внутрішньополітичної та соціальної ситуації в країні, дезорганізацію функціонування органів державної влади, важливих державних та військових об'єктів. Незважаючи на жорсткий та тоталітарний характер державної системи Росії, влада країни визнає існування загрози виникнення “кольорових" революцій на російській території;

діяльність терористичних організацій та окремих осіб, спрямована на підрив суверенітету, порушення єдності та територіальної цілісності Російської Федерації; створення незаконних збройних формувань та їх діяльність на території Росії та її союзників. 3 огляду на особливості внутрішньої ситуації в РФ, насамперед під такими загрозами розуміється збереження терористичних угруповань на Північному Кавказі.

Відповідно до визначеного переліку загроз, перед збройними силами Росії ставляться такі загальні завдання [3]:

стратегічне (ядерне та неядерне) стримування противників;

відбиття зовнішньої агресії проти РФ і їі союзників та нанесення військам агресора втрат, які б змусили його припинити військові дії на російських умовах;

захист громадян Російської Федерації за межами країни;

участь в операціях 3 підтримання (відновлення) миру та безпеки;

виконання міжнародних зобов'язань Росії 3 колективної безпеки та в рамках двосторонніх угод з іншими країнами;

боротьба 3 тероризмом на території Російської Федерації та попередження міжнародної терористичної діяльності за їі межами.

По суті, виклики і загрози безпеці Росії у військовій сфері та завдання іiі збройних сил, викладені у Воєнній доктрині країни, передбачають можливість:

участі Російської Федерації у військових конфліктах із США та НАТО, а також Китаєм i Японією, зокрема у формі широкомасштабної війни із застосуванням ядерної зброї;

силових дій Російської Федерації проти країн колишнього СРСР для встановлення контролю над ними під приводом захисту російських громадян та російськомовного населення;

проведення Росією військових операцій у зонах їі інтересів в інших регіонах світу під виглядом надання допомоги союзникам та миротворчої чи контртерористичної діяльності;

залучення збройних сил Росії для придушення внутрішніх заворушень в країні внаслідок дій екстремістів різної спрямованості або виступів противників діючої влади, які можуть бути видані за 
терористів.

Практичне відпрацювання наведених завдань здійснюється в рамках навчань, перевірок та інших заходів оперативної i бойової підготовки (ОБП) збройних сил Росії. Найбільшими 3 них є стратегічні командноштабні навчання серії "Захід”, “Кавказ”, "Центр" та "Схід”, які є підсумковими етапами ОБП ЗС РФ у рік їх проведення. Згадані навчання систематично проводяться 32007 року після проголошення В. Путіним курсу на конфронтацію із Заходом у рамках його виступу на щорічній Мюнхенській конференції з питань міжнародної безпеки [3].

Аналіз задуму та сценаріїв цих та інших навчань дає змогу дійти висновку щодо відпрацювання Росією різних сценаріїв війн і збройних конфліктів 3 Україною, Грузією, США/НАТО, Японією та Китаєм, а також проведення контртерористичних операцій на російській території [3].

До того ж, як один 3 основних театрів військових дій (ТВД) розглядається ПівденноЗахідний стратегічний напрямок Чорноморський регіон (включаючи Україну та Грузію) [3].

Практично Російська Федерація розпочала реалізацію своїх агресивних планів стосовно України під виглядом “гібридноі”" війни із застосуванням своїх ЗС [4].

Передбачаючи можливий напад НАТО на Росію у Чорноморському регіоні, зокрема для встановлення контролю над Кримом, РФ до того ж розглядає варіанти проведення Альянсом наступальної операції через Україну та Грузію, що супроводжуватиметься висадкою десантів у Криму та на Чорноморському узбережжі РФ [3, 4].

Наступний сценарій - перехід до проведення наступальної операції проти України (у випадку виникнення сприятливих умов) - під виглядом дій “ополченців” або під приводом захисту російських громадян i російськомовного населення.

Проведення обмеженої наступальної операції 3 району збройного конфлікту на Донбасі 3 метою оточення та захоплення м. Маріуполь, а також створення вихідних позицій для подальшого розгортання наступу у західному напрямку.

\section{Проведення}

наступальної операції сухопутного коридору до Криму та Придністров'я, а в разі успіху - окупації східних та південних регіонів України.

Виконання згаданих завдань покладається на сили та засоби Південного військового округу (ПдВО), 4-ї армії ВПС та ППО, а також Чорноморського флоту та Каспійської флотилії ЗС РФ [3, 4].

В окупованому Криму створено потужне угруповання. По класифікації НАТО - зона A2/AD (англ. Anti-access and area denial обмеження i заборона доступу i маневру). Основним озброєнням зони є сучасні оперативно-тактичні ракетні комплекси сухопутного i морського базування ("Іскандер" і "Калібр"), берегові протикорабельні комплекси (“Бастіон” і “Бал”), ракетні комплекси ППО (С-300, С-400, Бук-М2, “Панцир"), комплекси радіоелектронної боротьби тощо. До того ж ракети комплексів "Іскандер", “Калібр" і "Бастіон” здатні нести ядерну бойову частину. За радіусом дії вони можуть досягати цілі на території країн Балтії, Польщі, Чехії, Словаччини, Австріі, Румунії, Болгаріі, Грузї, Вірменіі, Азербайджану та Греції, включно 3 островом Крит, всіх балканських країн, Туреччини, Кіпру, Сирії, Лівану, Ізраїлю, Ірану та Іраку, узбережжя Сгипту, півдня Італії не кажучи про Україну. Також ідентична Зона є в Краснодарі.

Не виключено, що Російська Федерація вперто не полишає спробу створення катастрофи загальносвітового рівня. Це підтверджує і сам В. Путін, який, наприклад, у фільмі В. Соловйова “Світовий порядок 2018”, не відкидає можливості застосування ядерної зброї проти противників Росії (як це передбачається Воєнною доктриною РФ) навіть якщо це закінчиться глобальною катастрофою. За словами російського президента “...Навіщо нам такий світ, якщо там не буде Росіï?”, що таким чином демонструє справжню сутність "Руського світу” та методи його побудови [5].

Підтвердженням стратегічного ядерного стримування противників були показові за характером одночасні навчання стратегічних ядерних сил Росії та США в жовтні 2017 року. Так, під час навчань російської ядерної тріади виконувались навчально-бойові пуски міжконтинентальної балістичної ракети (МБР) “Тополь” з космодрому Плесецьк по полігону Кура (Камчатка), двох МБР підводним човном Тихоокеанського флоту з Охотського моря по полігону Чіжа (Архангельська обл.) та однієї МБР підводним човном Північного флоту по полігону Кура. А літаки дальньої (бомбардувальної) авіації повітряно-космічних сил РФ Ту-160, Ту-95МС, Ту-22М3 виконали пуски крилатих ракет по полігонах Кура, 
Пембой (Республіка Комі) та Теректа (Казахстан) [6].

Такі дії Росії суттєво занепокоїли керівництво НАТО та країн Балтії і Польщі, які вжили комплекс заходів із запобігання можливій російській військовій агресії. Зокрема, крім сухопутного військового компонента, було посилено стратегічний ядерний компонент ЗС США в Свропі. Так на авіабазу Ферфорд у Великобританії передислоковано п'ять стратегічних бомбардувальників В-52Н та В-1В ВПС США. Уперше від часу закінчення "холодної війни" у 1991 році такі літаки розпочали польоти над Балтійським морем. Низку навчань ОЗС НАТО у Балтійському регіоні було проведено i безпосередньо під час СКШН “Захід-2017” [6].

Загалом такі процеси значно збільшують військову напруженість у світі, та Європі зокрема, що також підвищує рівень військових загроз для України.

Висновки. 3 проведеного аналізу випливає, що ситуація довкола України становить основну загрозу іiі національній безпеці, залишається ймовірна збройна агресія Росії, яка, незважаючи на певне зниження інтенсивності бойових дій на Донбасі, готова до військового вторгнення в Україну, і навіть у вигляді повномасштабної наступальної операції.

Причинами вторгнення 3 більшою вірогідністю буде:

спроба, з боку України, розв'язання конфлікту на Донбасі збройним шляхом (імовірні дії РФ- проведення миротворчої операції із захисту прав i свобод російськомовного населення цих районів);

Стаття надійшла до редакційної колегії 18.10.2019 нарощування військового потенціалу НАТО та розгортання американської системи протиракетної оборони на території України (імовірні дії РФ - уведення угруповань військ під виглядом “зелених чоловічків" або проведення повномасштабної наступальної операції із завданням зайняти територію лівого берегу Дніпра та Півдня України або по кордону).

У подальших дослідженнях $\epsilon$ необхідність проаналізувати завдання, принципи та форми бойового застосування ЗС РФ за досвідом стратегічних командноштабних навчань серії “Захід”.

\section{СПИСОК ВИКОРИСТАНОЇ ЛІТЕРАТУРИ}

1. Воєнна доктрина Pociï. 2014. URL: https://militaryarms.ru.

2. Стратегія національної безпеки РФ. 2015. URL: https://rg.ru>nac-bezopasnost-sate-doc.

3. Завдання, принципи та форми бойового застосування Збройних Сил Росії на основних стратегічних (операційних) напрямках за досвідом стратегічних командно-штабних навчань URL: https// www.bintel.com.ua.

4. Січень I. Організована злочинність як інструмент “гібридних" війн Росії. Бінтел (журнал геополітичної аналітики). 2018. № 2 (10). С. 20 29.

5. Гвоздь В. Філософія "Руського світу" як Незимида для Росії. Бінтел (журнал геополітичної аналітики). 2018. № 2 (10). С. 419.

6. Гвоздь В. Особливості розвитку Ситуації у світі в 2017 році в контексті національних інтересів України. Бінтел (журнал геополітичної аналітики). 2017. № 4 (8). С. 18-27.

Куртсеитов Т. Л., д-р техн. наук, профессор;

Павлунько Н. Я., канд. воен. наук;

Посмитюх О. И., канд. воен. наук, доцент

Институт обеспечения войск (сил) и информационных технологий Национального университета обороны Украины имени Ивана Черняховского, Киев.

Анализ основных вызовов и угроз Российской Федерации в военной сфере: основа применения ее вооруженных сил на Южно-Западном стратегическом направлении

Резюме. В статье на основе анализа положений новой Стратегии национальной безопасности Российской Федерации, военной доктрины и научных публикаций, в которых рассматриваются внешняя политика России, сформулированы стратегические цели внешней политики России, основные приоритетные направления в сфере национальной безопасности определенных перед Вооруженными Силами Российской Федерации, перечень основных вызовов и угроз Российской Федерации в военной cферe.

На основе перечня основных вызовов и угроз определены основные задачи, которые ставятся перед вооруженными силами России и основные формы их применения в военных конфликтах.

Опираясь на анализ планов учений, проведенных Российской Федерацией в последние годы, в статье предоставлены выводы относительно планируемых сценариев войн и вооруженных конфликтов с Украиной, Грузией, США/НАТО, Японией и Китаем, а также проведения контртеррористических операций на российской территории. 
Определено, что ситуация вокруг Украины составляет основную угрозу ее национальной безопасности, остается вероятная вооруженная агрессия России, которая, несмотря на некоторое снижение интенсивности боевых действий на Донбассе, готова к военному вторжению в Украину, в т. ч. в виде проведения миротворческой операции или полномасштабной наступательной операции.

Ключевые слова: вызовы; угрозы; военная сфера; стратегическое направление.

\section{T. Kurtseitov, DsT (Technical), professor;}

M. Pavlunko, PhD (Military);

O. Posmitukh, PhD (Military), assistant professor

Institute for providing troops (forces) and information technologies of the Ivan Chernyakhovskyi National University of Defense of Ukraine, Kiev.

Analysis of the main challenges and threats of the Russian Federation in the military sphere: the basis of the use of its armed forces in the South-West strategic direction

Resume. Based on the analysis of the provisions of the new National Security Strategy of the Russian Federation, military doctrine and scientific publications that examine the foreign policy of Russia, the strategic objectives of Russia's foreign policy are formulated, the main priority areas in the field of national security identified before the Armed Forces of the Russian Federation, a list of the main challenges and threats of the Russian Federation in the military sphere.

Based on the list of the main challenges and threats, the main tasks that are set for the Russian armed forces and the main forms of their use in military conflicts are determined.

Based on an analysis of the exercise plans conducted by the Russian Federation in recent years, the article provides conclusions regarding the planned scenarios of wars and armed conflicts with Ukraine, Georgia, the USA/NATO, Japan and China, as well as counter-terrorism operations on Russian territory.

It is concluded that the situation around Ukraine constitutes the main threat to its national security, the likely armed aggression of Russia remains, which, despite a slight decrease in the intensity of hostilities in the Donbass, is ready for a military invasion of Ukraine, including in the form of a peacekeeping operation or fullscale offensive operation.

Keywords: the challenges; the threats; the military sphere; the strategic direction. 